Türkiye Mesleki ve Sosyal Bilimler Dergisi, Ağustos 2021, Yıl: 3, Sayı: 6, 1-9.

Journal of Vocational and Social Sciences of Turkey, Aug 2020, Year: 3, No: 6, 1-9.

ARAŞTIRMA MAKALESİ / RESEARCH ARTICLE

Atıf için /for cited: Doğan, H., Dengiz C.C., Doğan,M.Y . (2021). Factors in Gastronomy Tourism Giving Local Foods a Competitive Advantage. Journal of Vocational and Social Sciences of Turkey, Yll: 3, Sayl: 6, Ağustos 2021, s.1-9.

\title{
FACTORS IN GASTRONOMY TOURISM GIVING LOCAL FOODS A COMPETITIVE ADVANTAGE
}

\section{Hulusi DOĞAN*}

\author{
Celal Cem DENGiz**
}

\author{
Meliha Yaren DOĞAN***
}

\begin{abstract}
Gastronomy tourism is one of the youngest and fastest growing branches of tourism. Therefore, it can be said that different searches and expectations for gastronomy tourism have manifested themselves in tourism with food and drink. In this sense, tourists' search for different tastes, different flavors and experiences have brought a new perspective and a new dimension to tourism. Being able to experience different tastes in different geographies means a different excitement and a special memory for tourists. These real destinations have pushed tourism professionals to think about local foods once again and to a serious competition process. Therefore, nowadays, each region, each city and each destination is in search of developing strategies and policies to offer and market their unique local foods to the tourism industry.

Destinations are aware that difference and originality are the basis of creating competitive advantage. With this awareness, it strives to identify and protect the elements that give life to its local foods and give them privilege. This effort is not only a sustainable competitive advantage, but also a prerequisite for leaving local foods to future generations.

This study focuses on the place and importance of local foods in gastronomy tourism. The advantages of local foods to destinations in gastronomy tourism are discussed. In addition, local food characteristics and factors that give competitive advantage to local foods are analyzed in depth. The factors that add originality to local foods and limit their imitability are presented and examined in this study in concrete. Concrete suggestions and solutions are also offered to all stakeholders to identify and develop the elements that provide competitive advantage to local foods.
\end{abstract}

Keywords: Gastronomy tourism, local food, competitive advantage, strategy.

Jel Code: Z30, Z32, Z33.

\section{GASTRONOMI TURIZMINDE YEREL ÜRÜNLERE REKABET AVANTAJI KAZANDIRAN UNSURLAR}

\section{ÖZET}

Gastronomi turizmi, turizmin en genç ve en hızlı gelişen dallarından bir tanesidir. Dolayısıyla gastronomi turizmi için, farklı arayış ve beklentilerin turizmde yiyecek içecekle kendini göstermiş halidir de denilebilir. $\mathrm{Bu}$

\footnotetext{
* (D) Muğla Sıtkı Koçman Üniversitesi, Turizm Fakültesi, Yiyecek ve İçecek İşletmeciliği Bölümü, Prof.Dr., hulusidogan@mu.edu.tr

** (D) Muğla Sıtkı Koçman Üniversitesi, Sosyal Bilimler Enstitüsü, Yenilikçilik ve Girişimcilik Anabilim Dalı, Yüksek Lisans Öğrencisi, celal_cem@hotmail.com

*** (D) Muğla Sıtkı Koçman Üniversitesi, Sosyal Bilimler Enstitüsü, Turizm İşletmeciliği Anabilim Dalı, Yüksek Lisans Öğrencisi, doganyaren257@gmail.com
} 


\section{TÜRKIYE MESLEKI VE SOSYAL BILIMLER DERGISi}

Türkiye Mesleki ve Sosyal Bilimler Dergisi, Ağustos 2021, Yıl: 3, Sayı: 6, 1-9. Journal of Vocational and Social Sciences of Turkey, Aug 2020, Year: 3, No: 6, 1-9.

anlamda turistlerin farklı tat, farklı lezzet arayış ve deneyimleri turizme yeni bir bakış, yeni bir boyut kazandırmıştır. Farklı coğrafyalarda, farklı lezzetler deneyimleyebilmek turistler için ayrı bir heyecan, ayrı bir hatıra anlamına gelmektedir. Bu gerçek destinasyonları yerel ürünler (local foods) üzerinde bir kez daha düşünmeye ve ciddi bir rekabet sürecine itmiştir. Dolayısıyla günümüzde her bir bölge, her bir kent, her bir destinasyon kendine özgü yerel ürünleri turizm endüstrisine sunma ve pazarlamaya yönelik strateji ve politikalar geliştirme arayışı içindedir.

Destinasyonlar rekabet avantajı yaratmanın temelinde de farklılık ve özgünlük olduğunun bilincindedir. Bu bilinçle yerel ürünlerine hayat veren, onlara ayrıcalık kazandıran unsurları belirleme ve koruma çabası içindedir. $\mathrm{Bu}$ çaba sürdürülebilir bir rekabet avantajı yaratmanın yanı sıra yerel ürünleri gelecek nesillere bırakabilmenin de ön koşuludur.

Bu çalışma da gastronomi turizminde yerel ürünlerin yeri ve önemini konu edinmektedir. Gastronomi turizminde yerel ürünlerin destinasyonlara sağlayacağı avantajlar ele alınmaktadır. Ayrıca yerel ürün özellikleri ile yerel ürünlere rekabet avantajı kazandıran unsurlar derinlemesine analiz edilmektedir. Yerel ürünlere özgünlük katan ve taklit edilebilirliğini kısıtlayan unsurlar bu çalışmada somut olarak sunulmakta ve incelenmektedir. Yerel ürünlere rekabet avantajı sağlayan unsurların belirlenmesi ve geliştirilmesine yönelik tüm paydaşlara da somut öneri ve çözümler sunulmaktadır.

Anahtar Kelimeler: Gastronomi turizmi, yerel ürün, rekabet avantaj1, strateji.

Jel Kodu: Z30, Z32, Z33.

\section{INTRODUCTION}

The desire of people to taste different tastes in travel decisions and travel processes can be among the main determinants. This means that gastronomy tourism has increased its share and importance in the tourism sector. Participating in food and beverage festivals, visiting food producers, visiting restaurants and special places and tasting different tastes are the main components of gastronomic tourism. On the other hand, local foods are among the indispensable elements of gastronomic tourism (Kivela and Crotts 2006; Guruge, 2020; Alonso and Liu, 2011; McKercher, 2008; Green and Dougherty, 2008; Altıntaş ve Hazarhun, 2020). In the context of creating difference and originality, local foods have a special value for both tourists and local economies. However, first of all, it is necessary to understand what the local product is.

Local food means the product that is produced and consumed within a certain geographical area. Generally, this area is considered to be 100 miles (about $161 \mathrm{~km}$ ). Therefore, food produced and consumed within an area of 100 miles is qualified as local food. Another important point is that local foods can be purchased directly from their producer. It is purchased and consumed from local producers without intermediaries. Due to the lack of intermediaries, there is a gain and development of the local economy. In other words, it means protecting and supporting local producers. Similarly, it is possible that there are no intermediaries and that the local foods are produced and consumed within a certain geographical area and there is no or minimization of transportation processes and costs in local foods. This minimizes the distance between the production area and the kitchen table. In other words, it is less fossil fuel consumption and carbon dioxide emission. Therefore, it contributes to the national economy and the protection of the environment. Local foods also have advantages in terms of food safety. Buying from local producers also means minimizing potential food contamination. Because it is possible to minimize human touch and eliminate the use of possible additives for the protection of food during transportation and storage. This is a positive approach in terms of food safety. All of these stand out as the main characteristics of local food (Coley et al., 2009; Carpio and Isengildina-Massa, 2009; Blanke and Burdick, 2005; Abate, 2008; Giraud et al., 2005). However, it is inevitable to examine local foods in the context of the factors that make them advantageous for gastronomic tourism. Knowing the factors that give life to local foods in the context of creating competitive advantage will guide the development of correct policies and strategies. It will also contribute to the production and marketing of local foods as well as their transmission to future generations as a cultural heritage. 


\section{TÜRKIYE MESLEKI VE SOSYAL BILIMLER DERGISI}

Türkiye Mesleki ve Sosyal Bilimler Dergisi, Ağustos 2021, Yıl: 3, Sayı: 6, 1-9.

Journal of Vocational and Social Sciences of Turkey, Aug 2020, Year: 3, No: 6, 1-9.

\section{LOCAL FOODS AND COMPETITIVE ADVANTAGE}

We collect the elements that give competitive advantage/originality to local foods under 5 headings. The relationship between these elements and the authenticity of local foods is illustrated in Figure 1 . The horizontal axis in the figure shows the number of elements that give local food competitive advantage/originality. The number of elements increases towards the right and decreases towards the left. The vertical axis shows the competitive advantage /originality level of local foods. Uniqueness increases as you go upwards, and decreases downwards. Therefore, the more the number of ingredients in a local food, the higher the level of originality. As the number of elements decreases, the authenticity level of the local food decreases. These elements that give originality to local foods are as follows:

\subsection{Endemicness}

The fact that a plant grows only in a certain region or area in the world is expressed as "endemicness". This means that the plant itself is a unique and rare value. In other words, it means that it is advantageous in terms of competition due to its nature. However, it should not be forgotten that not every endemic plant is eatable. Therefore, being both endemic and eatable are two basic elements that add originality and locality to a plant in terms of gastronomy tourism. The existence of such a plant provides a fundamental advantage to the local or regional people in terms of competitive advantage from the very beginning. Because the owner of this plant, this flavor, and the control of offering it to gastronomic tourism are in the hands of the local people.

Figure 1. Competitive Advantage Elements of Local Foods

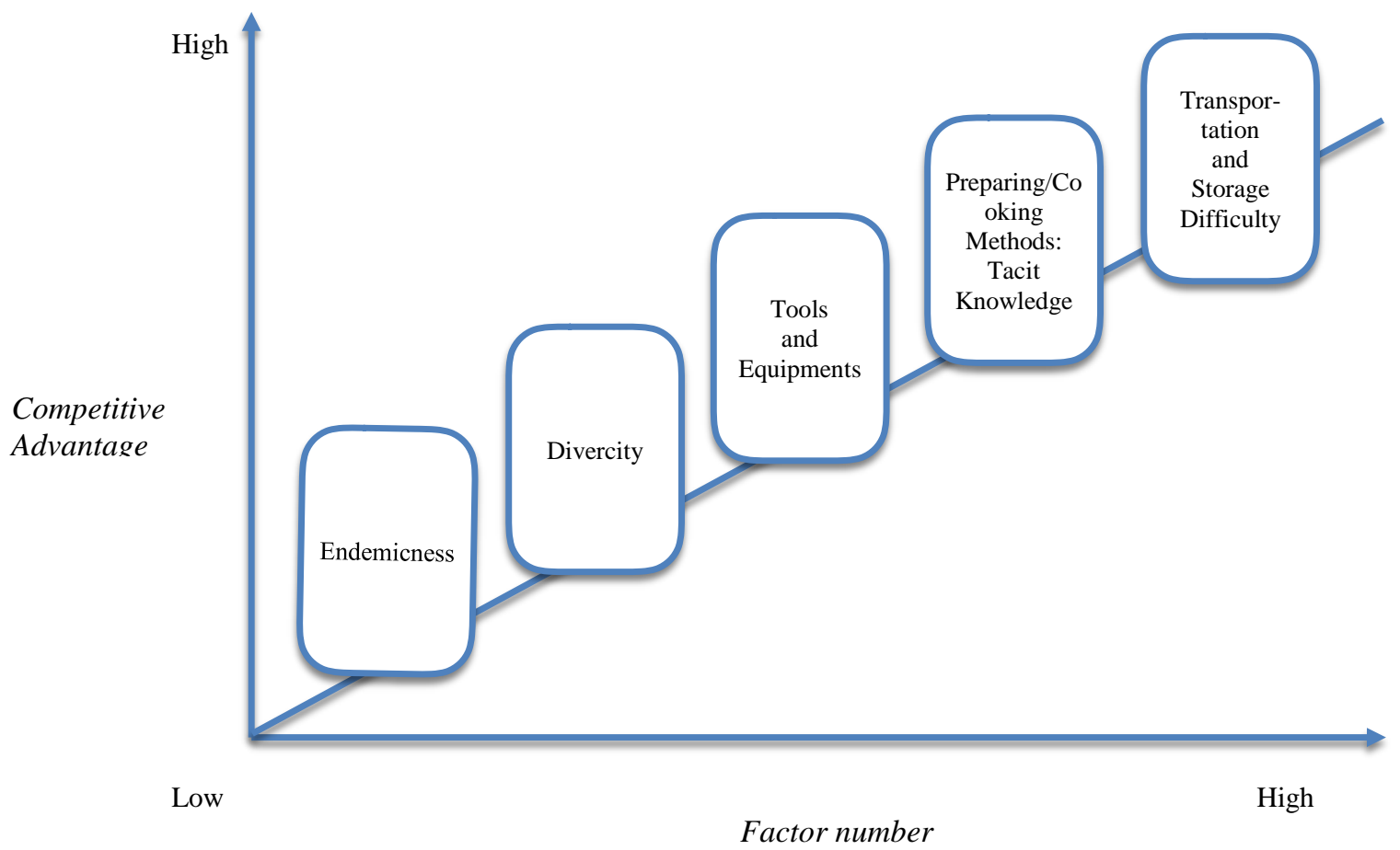

It is not possible to imitate this flavor that can only grow in a certain region with water, air and soil components. Therefore, we can say that the main source of competitive advantage is the plant itself. It is possible to find such edible endemic plants both in the world and in our country. For example, 


\section{TÜRKIYE MESLEKI VE SOSYAL BILIMLER DERGISI}

Türkiye Mesleki ve Sosyal Bilimler Dergisi, Ağustos 2021, Yıl: 3, Sayı: 6, 1-9. Journal of Vocational and Social Sciences of Turkey, Aug 2020, Year: 3, No: 6, 1-9.

"akebi" that grows only in the north of Japan in the world is an endemic fruit. It is impossible to find this fruit, collected in the autumn, in markets. In order to taste this fruit, it is necessary to be in the place and period it is grown. 'Tamarillo', which grows in Galapagos Islands, 'kiwano', which grows in Sub-Saharan Africa, and 'passion fruit' that grows in South America can be given as examples of such fruits. There are endemic plants that are also grown and consumed in our country. For example, "cheepwood" (Ranunculus poluninnii) and "Bitlis Çöveni" (Gypsophila bitlisensis) which added to Van herbal cheese, are some of these endemic plants (photograph 1). In addition, "rock lettuce" (Limonium effusum) grown in the Aegean Region and "devetaban1" (Eryngium campestre) grown in the Bodrum Peninsula are endemic plants consumed in salads and meals. Endemic plants such as "Lamb's Tongue" (Sideritis congesta) grown in Mersin, Karaman and Antalya provinces are also consumed in the form of tea in our country. In addition to creating a competitive advantage in gastronomy tourism, it should not be forgotten that endemic plants may face the danger of extinction. (Kifer, 2016; Torlak, 2009).

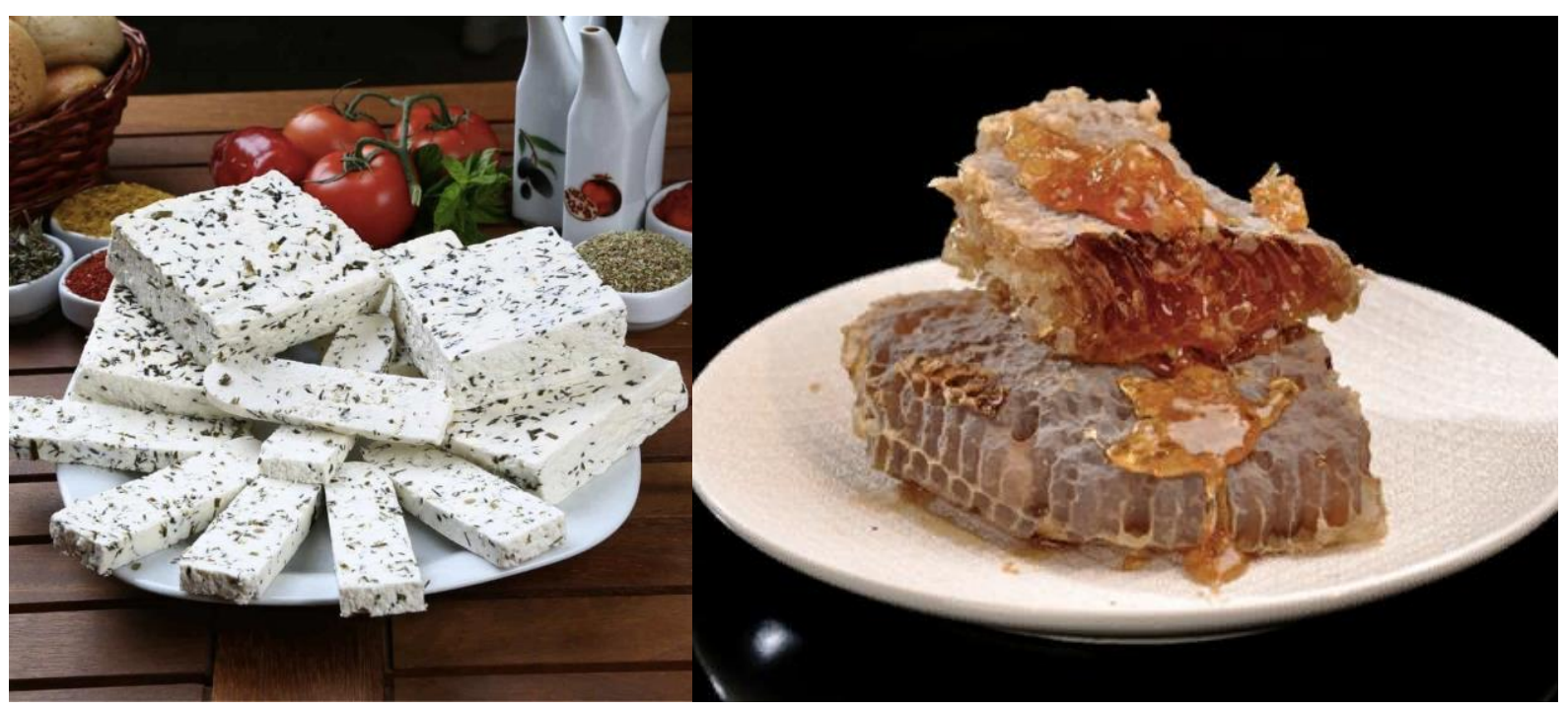

Photograph 1. Van Herbal Cheese and Anzer Honey

\subsection{Diversity}

It is the separation of a plant or food from its counterparts with its quality and taste in a certain region. For example, bean is a plant that grows almost everywhere in the world and in our country. However, "İspir bean" differs from its counterparts in our country with its quality and taste. Likewise, the meat of animals that are spread and grown in a certain region can be differentiated from similar ones in terms of taste. The meat of the animals grown in a certain region can be more delicious and it can be preferred more because of the area it spreads and the herbs it eats. We can add the example of honey to this. Honey is also a food produced in many parts of the world. However, there are honeys that stand out from their counterparts with their quality and taste. For example, Anzer honey and Marmaris pine honey (photograph 1). Food and beverages made with these products, which differ from their counterparts in terms of taste and quality, are also different. However, it is clear that the main factors underlying this difference are naturalness and organicity. We can say that the main factor that distinguishes these products from their counterparts is that they are produced and collected naturally in their natural climate. This naturalness and organicity play a decisive role in the preservation of the localness of the food (Weber and Matthews, 2008; Hu et al., 2013; Thilmany et al., 2008). 


\section{TÜRKIYE MESLEKI VE SOSYAL BILIMLER DERGISI}

Türkiye Mesleki ve Sosyal Bilimler Dergisi, Ağustos 2021, Yıl: 3, Sayı: 6, 1-9. Journal of Vocational and Social Sciences of Turkey, Aug 2020, Year: 3, No: 6, 1-9.

\subsection{Tools and Equipment}

In addition to its ingredients, the tools used in its preparation or cooking can also make local foods different. As well as the materials used in a dish, the tools used in its cooking can also bear originalityTherefore, when you cook the same food with other tools other than these natural tools and equipment, you cannot achieve the same taste and quality. For example, you cannot find the taste of a meal or bread cooked in stone ovens in electric or micro-ovens. Because the stone oven itself has an originality as well as the food itself. The materials used in the construction of stone furnaces are not ordinary, and the dimensions and construction of stone furnaces require a different skill and skill. In addition, even the containers in which the food will be cooked together with the firewood to be burned in the stone ovens can be decisive in the quality of the meals. For example, suitable woods are selected according to the food to be cooked in stone ovens in order to achieve the desired heat and cooking quality. In this sense, mostly beech or hornbeam type woods are used in stone ovens. Also the containers in which the food will be cooked can add a different taste and flavor to the meal. Special pots are preferred for this (photograph 2). For example, pots produced with soils taken from Avanos Mountains and Kizllırmak beds in Anatolia are used. Like stone ovens, pottery are also works of art that add originality to the dish. It is the reflection of hundreds of thousands of years of knowledge and experience. Therefore, it is an integrated culture, identified with the tools and equipment with which it is cooked. Its locality and originality is hidden in the combination of these elements. Therefore, when one is missing, the spirit and feature of the whole is lost (Doğan, 2018; Bostanc1, 2018; Göde, 2017; Kilıçarslan, 2021).

Photograph 2. A Stone Oven and An Earthenware Pot
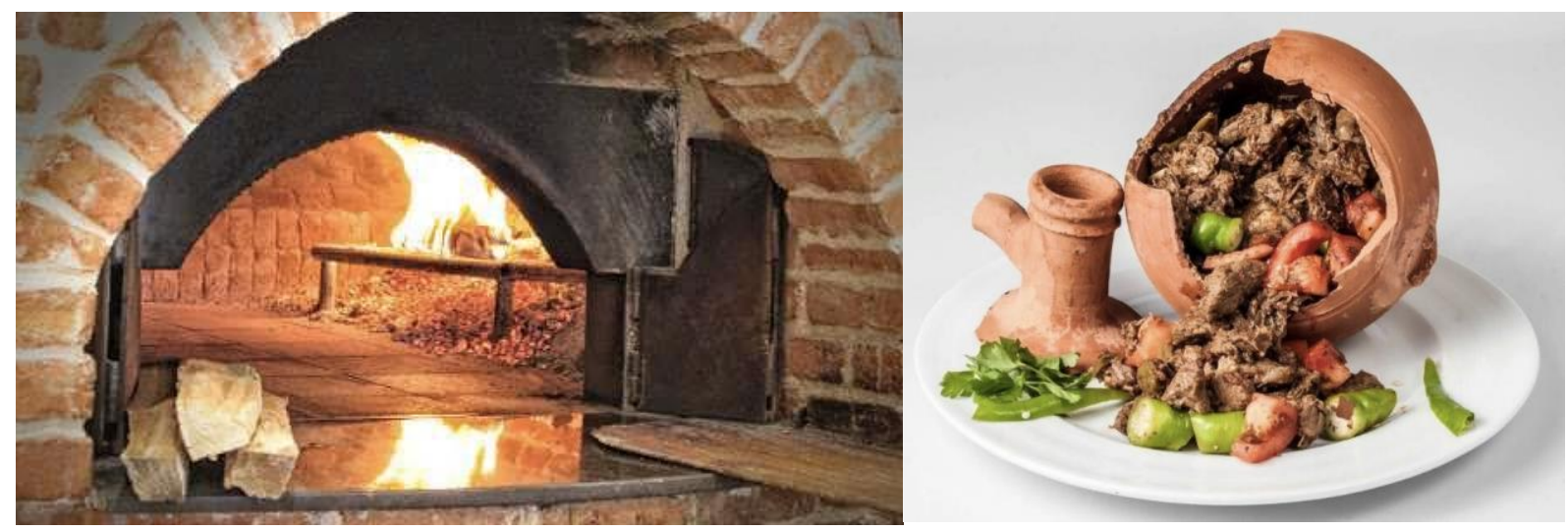

\subsection{Preparation / Cooking Ways and Methods}

The preparation and cooking method of each dish is as important as the ingredients to be put into it. Although the ingredients are exactly the same, it will not be possible to achieve the desired quality and taste unless the correct cooking methods are applied. Even if the cooking recipes are given in writing as well as the ingredient list, it is not always easy to achieve the desired taste. To put it more clearly, the preparation and cooking of a meal may require a long experience. For example, if all the ingredients and the recipes are given in writing, it is almost impossible to open a thin baklava dough (photograph 3). This is the accumulation of a long-term experience. It is not possible to obtain this skill in a short time. Moreover, you cannot acquire this skill by watching a baklava chef. You have to live effectively and experience for a long time. 


\section{TÜRKIYE MESLEKI VE SOSYAL BILIMLER DERGISI}

Türkiye Mesleki ve Sosyal Bilimler Dergisi, Ağustos 2021, Yıl: 3, Sayı: 6, 1-9. Journal of Vocational and Social Sciences of Turkey, Aug 2020, Year: 3, No: 6, 1-9.
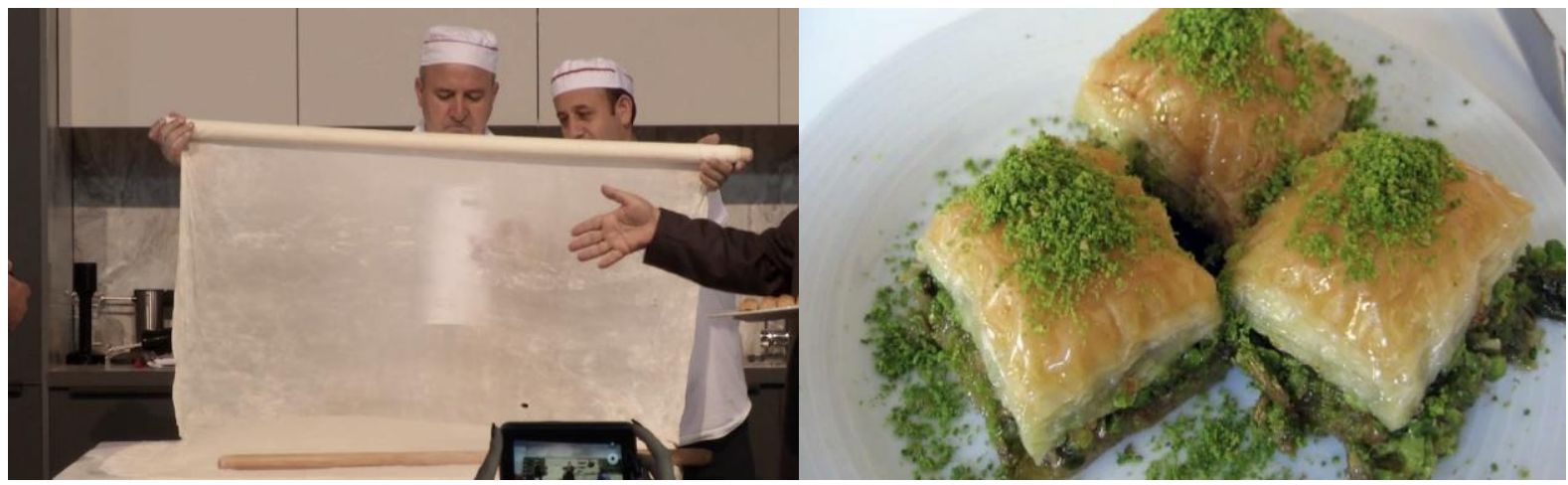

Photograph 3. A Thin Baklava Dough and Baklava

Because this skill is a type of tacit knowledge based on experience. Unlike explicit knowledge, tacit knowledge is based on action and experience. Tacit knowledge cannot be easily transcribed into words or writing, such as explicit information. You cannot describe the taste of strawberries with words to someone who has never tasted strawberries in her life. Therefore, the way to describe the taste of strawberries is not words, but to make the other person taste it. Tacit knowledge is action. It's not about telling someone how to get on a bike for hours, but to sit it at the head of the bike. Tacit knowledge is patience. The thought of the bike is to insist, not give up. Tacit knowledge is a masterapprentice relationship. It requires someone to be a role model for you with their experiences and actions. Tacit knowledge is not being able to tell, but to be able to live (Doğan, 2006; Lubit, 2001; Reed and DeFillippi, 1990) Therefore, even if they put all the recipes in front of you, you cannot cook a pastry like your mother or cook a meal like your grandmother. Even if you follow the exactly written recipes, you cannot prepare the dough prepared by a baklava master and you cannot get the same taste. Because this skill is knowledge acquired over many years, not in a day, a month or a year. Therefore, it is not the recipes that bring different tastes to life, but the skills and experience of many years. This experience is reflected in local foods as a difference and specificity.

Photograph 4. Beyran Soup and Adana Kebab

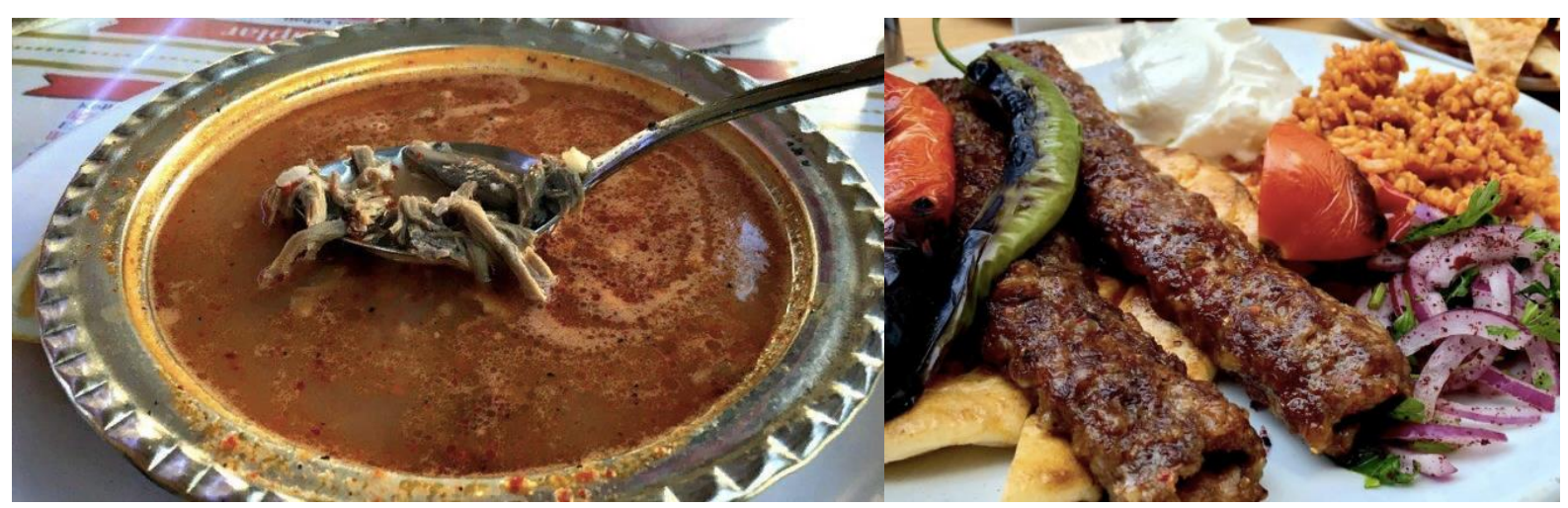

\subsection{Transportation and Storage Difficulty}

Food is an art in visual photographs and taste remains in the palate. You can paint this art, but you cannot frame its taste. Maybe you can save it in your memory, on your palate, but you cannot save it in your home or office. Because this art is a taste that is experienced at the moment it leaves the hands of its artist. You have to taste an Adana kebab as soon as it comes out of the hands of a kebab master 


\section{TÜRKIYE MESLEKI VE SOSYAL BILIMLER DERGISI}

Türkiye Mesleki ve Sosyal Bilimler Dergisi, Ağustos 2021, Yıl: 3, Sayı: 6, 1-9. Journal of Vocational and Social Sciences of Turkey, Aug 2020, Year: 3, No: 6, 1-9.

in Adana. Or you have to drink "a beyran soup" hot in Gaziantep. You cannot pack neither "Adana kebab nor beyran soup" to your hometown. Even if you take it, you will never find that taste you are looking for. Therefore, you cannot find the taste of the kebab you eat in Adana or "the tray kebab" you eat in Hatay anywhere else. Because these flavors are as natural and unique as they are served. In addition, it is almost impossible to achieve the same taste even if you supply the ingredients individually and take them to your country. Because it is a scientific fact that every natural element gives a reactive change as soon as it emerges from its own climate. It is clear that chemical preservatives to be used to prevent spoilage of natural products can be an opposite and threat to naturalness. Therefore, it is common for a food extracted from its own climate not to taste the same in different climates. For this reason, it is a different pleasure to taste every taste in its own climate (Hardest, 2008; Hu et al., 2013; Mariola, 2008; Selfa and Qazi, 2005; Thilmany et al., 2008).

\section{CONCLUSION}

It is known that tourism is a sector that continuously increases its share in the world. It is observed that the interest in tourism activities in different areas is constantly increasing by going beyond the seasand-sun triangle. Different tourism activities such as industrial tourism, sadness tourism, nature tourism, cultural tourism, health tourism, religious tourism are getting more and more attention day by day. Gastronomy tourism also has an important place in tourism activities. People's desire to taste different foods and beverages can be an important determinant in travel decisions. Especially in the monotonous world life, seeing different places as well as tasting different tastes is among the basic components of the travel motivation for today's people. The main address of difference in gastronomic tourism is local foods. Flavors specific to a particular region can give tourists a distinct pleasure and experience (Getz and Brown, 2006; Henderson, 2009; Çavuşoğlu ve Çavuşoğlu, 2018; Guruge, 2020; McKercher et al., 2008). In addition, these delicacies are an important source of competitive advantage in tourism for the region. What are the factors that give local flavors a competitive advantage in tourism is also of particular importance in this sense. Because knowing these factors will provide important benefits in terms of carrying local elements to the future as well as using them more effectively and successfully in tourism. Endemic species are the main factors that give local foods a competitive advantage. However, the basic condition is to protect and use such endemic plants without the danger of extinction. Although not endemic, species that differ from their counterparts with their taste are another element that gives local foods a competitive advantage. Preservation of their naturalness is another condition. Unique cooking tools and methods are also among the factors that give local foods a competitive advantage. Difficulty of transportation and preservation is another dimension of local foods that creates competitive power. The need to consume local foods in the moment and environment when they are prepared in terms of the desired taste can give it a distinct superiority and advantage.

It is possible to make a number of inferences and suggestions regarding local foods. First of all, it should not be forgotten that local foods are a cultural heritage. Therefore, it is our most important responsibility to protect this cultural heritage and pass it on to future generations. In the name of this responsibility, it should be one of the basic steps to determine the elements that give the food localness and originality. Then, registration of local foods with tools such as patents, brands, geographical indications should be another step. In gastronomy tourism, being able to promote local foods on the basis of the country and the world should be among our priority goals. In this sense, festivals, competitions, fairs, congresses can be among the important promotional tools. Including local foods in the curriculum of gastronomy schools may be another step in terms of their promotion and transfer to future generations. In addition, the fact that localness is originality and naturalness should be explained well. In this sense, it should not be overlooked that local foods also play an important role in protecting the environment. It should never be forgotten that for the success of all these steps, an effective harmony, coordination and cooperation of country, regional and local administrators will be needed. 


\section{TÜRKIYE MESLEKI VE SOSYAL BILIMLER DERGISi}

Türkiye Mesleki ve Sosyal Bilimler Dergisi, Ağustos 2021, Yıl: 3, Sayı: 6, 1-9. Journal of Vocational and Social Sciences of Turkey, Aug 2020, Year: 3, No: 6, 1-9.

\section{KAYNAKÇA}

Abate, G. (2008), "Local Food Economies: Driving Forces, Challenges, and Future Prospects," Journal of Hunger \& Environmental Nutrition, Vol. 3: 384-399.

Alonso, A. D. and Y. Liu, Y. (2011), "The potential for marrying local gastronomy and wine; the case of the fortunate islands", International Journal of Hospitality Management, 30: 974-981.

Altıntaş, V. ve Hazarhun, E. (2020), “İzmir'in Gastronomi Turizmi Potansiyeline Turist Rehberlerinin Bakış Açıları", International Journal of Applied Economic and Finance Studies”, Vol. 5 (2): 13-36.

Blanke, M. M. and Burdick B. (2005), "Food (miles) for Thought", Environmental Science and Pollution Research, Vol. 12: 125-127.

Bostanc1, S. (2018), “Taş firında pişer mahalleye düşer”, https://www.aa.com.tr/tr/yasam/tas-firinda-pisermahalleliye-duser/1281260, Date Accessed: 13.05.2021.

Carpio, C.E. and Isengildina-Massa, O. (2009), "Consumer Willingness to Pay for Locally Grown Products: The Case of South Carolina", Agribusiness, Vol. 25: 412-426.

Coley, D., Howard, M. and Winter, M. (2009), "Local Food, Food Miles and Carbon Emissions: A Comparison of Farm Shop and Mass Distribution Approaches", Food Policy, Vol. 34: 150-155.

Çavuşoğlu, M. ve Çavuşoğlu, O. (2018), "Gastronomi Turizmi ve Kıbrıs Sokak Lezzetleri Üzerine Bir Araştırma”, Güncel Turizm Araştırmalarl Dergisi, 637-651.

Doğan, H. (2006), "The Search of Tacit Knowledge in Akhism Culture”, Kocaeli Üniversitesi Sosyal Bilimler Enstitüsü Dergisi ,12 (2) : 22-38.

Doğan, H. (2018), "İnsanlık tarihi kadar eski bir sanat: Çömlekçilik”, http://www.turktarim.gov.tr/Haber/82/insanlik-tarihi-kadar-eski-bir-sanat-comlekcilik, Date Accessed: 13.05.2021.

Getz, D. and Brown, G. (2006), "Critical success factors for wine tourism regions: A demand analysis", Tourism Management, 27 (1): 146-158.

Giraud K.L., Bond C.A., Bond J.J. (2005), "Consumer preferences for locally made specialty food products across Northern New England”, Agricultural and Resource Economics Review, 34: 204-216.

Göde, H. A. (2017), Kültür endüstrisine örnek olarak Isparta/Yalvaç ekmek kültürü ve dünden bugüne mahalle firınc1lı̆̆ı", folklor/edebiyat, 23 (91): 197-210.

Green, G. P. and Dougherty, M. L. (2008), "Localising link ages for food and tourism: culinary tourism as a community development strategy”, Community Development, 39 (3): 148-158.

Guruge, M. C. B. (2020), "Conceptual Review on Gastronomy Tourism”, International Journal of Scientific and Research Publications, Vol. 10 (2): 319-325.

Hardesty, S. D. (2008), “The Growing Role of Local Food Markets”, American Journal of Agricultural Economics, Vol. 90: 1289-1295.

Henderson, J.C. (2009), "Food Tourism Reviewed”, British Food Journal, 111(4), 317-326.

Hu W., Qing, P., Batte, M., Woods, T. and Ernst, S. (2013),"What is local and for what foods does it matter?", Agricultural Economics, 59(10): 454-466.

Kılıçarslan, İ. (2021), "Tam 600 yıllık çömlekçilik geleneğini yaşatıyorlar”, https://www.sozcu.com.tr/hayatim/yasam-haberleri/tam-600-yillik-comlekcilik-gelenegini-yasatiyorlar/, Date Accessed: 13.05.2021.

Kifer, C. (2016), "15 unusual fruits to try from around the world”, https://everintransit.com/exotic-fruits, Date Accessed: 13.05.2021.

Kivela, J. and Crotts, J. (2006), “Tourism and Gastronomy: Gastronomy's Influence on How Tourists Experience a Destination", Journal of Hospitality \& Tourism Research, Vol. 30: 354-377.

Lubit, R. (2001), Tacit Knowledge and Knowledge Management: The Keys to Sustainable Competitive Advantage, Organizational Dynamics, Vol. 29, No. 4: 164-178.

Mariola, M. J. (2008), "The Local Industrial Complex? Questioning the Link Between Local Foods and Energy Use", Agriculture and Human Values, Vol. 25: 193-96.

McKercher, B., Okumus, F. and Okumus, B. (2008), "Food tourism as a viable market segment: it's all how you cook the numbers", Journal of Travel \& Tourism Marketing, 25 (2): 137-148.

Reed, R. and DeFillippi, J. R. (1990), "Casual Ambiguity, Barriers to Imitation, and Sustainable Competitive Advantage", Academy of Management Review, Vol. 15, No. 1: 88-102.

Selfa, T. and Qazi, J. (2005), "Place, Taste, or Face-to-Face? Understanding Producer-Consumer Networks in 'Local' Food Systems in Washington State", Agriculture and Human Values, Vol. 22: 451-464.

Thilmany D., Bond C.A., Bond J.K. (2008), "Going local: Exploring consumer behavior and motivations for direct food purchases", American Journal of Agricultural Economics, 90: 1303-1309. 


\section{TÜRKIYE MESLEKI VE SOSYAL BILIMLER DERGISI}

Türkiye Mesleki ve Sosyal Bilimler Dergisi, Ağustos 2021, Yıl: 3, Sayı: 6, 1-9.

Journal of Vocational and Social Sciences of Turkey, Aug 2020, Year: 3, No: 6, 1-9.

Torlak, H. (2009), "Yediğimiz-içtiğimiz endemik bitkilerimiz”,

https://bilimvegelecek.com.tr/index.php/2009/02/01/yedigimiz-ictigimiz-endemik-bitkilerimiz, Date Accessed:08.05.2021.

Weber, C.L. and H.S. Matthews, H. S. (2008), "Food-Miles and the Relative Climate Impacts of Food Choices in the United States", Environmental Science and Technology, Vol. 42: 3508-3513. 